\title{
Evolving Consumption Patterns of Various Information Media via Handheld Mobile Devices
}

\author{
Ruti Gafni \\ The Academic College of \\ Tel Aviv Yaffo, Israel and \\ The Open University of \\ Israel, Raanana, Israel
}

\author{
Nitza Geri \\ The Open University of Israel, \\ Raanana, Israel
}

nitzage@openu.ac.il rutigafn@mta.ac.il

\begin{abstract}
This study examines diverse information media in order to identify those formats that are most suitable for consumption via handheld mobile devices, namely, smartphones and tablets. The preferences of the users are measured objectively by analyzing actual data of their relative use of handheld mobile devices and personal computing (PC) desktop devices, including laptops and notebooks, for consumption of information presented in various formats. Our findings are based on Google Analytics pageview data of five course Websites during a period of three semesters, by 11,557 undergraduate students. M-learning contexts were chosen, since in a learning environment the interests of information providers (i.e., the instructors) are in accord with those of the information consumers (i.e., the students), whereas in commercial settings there may be conflicts of interests. Our findings demonstrate that although about $90 \%$ of the pageviews were via PC devices, the rate of smartphone use for consuming learning content in diverse information media is gradually increasing as time goes by, whereas the rate of tablet use for these purposes is stagnant. The most promising direction for smartphone development, emanating from the findings, is online video content.
\end{abstract}

Keywords: mobile applications acceptance, information format, information media, instructional media, mobile learning (m-learning), diffusion of innovation, human computer interaction.

\section{Introduction}

Websites provide information through various media, like text, video, and audio. The majority of this information was designed for being consumed via desktop devices, i.e., personal computers,

Material published as part of this publication, either on-line or in print, is copyrighted by the Informing Science Institute.

Permission to make digital or paper copy of part or all of these works for personal or classroom use is granted without fee provided that the copies are not made or distributed for profit or commercial advantage AND that copies 1) bear this notice in full and 2) give the full citation on the first page. It is permissible to abstract these works so long as credit is given. To copy in all other cases or to republish or to post on a server or to redistribute to lists requires specific permission and payment of a fee. Contact Publisher@InformingScience.org to request redistribution permission. and laptops, as well as notebooks, although to a lesser extent. The evolution of mobile technology, particularly the emergence of smartphones and tablets, enabled ubiquitous access to the Internet in order to consume information. In recent years, the use of mobile phones has been extended from voice calls to interactive services and information provided in diverse formats. According to Duggan and Rainie (2012), at least $85 \%$ of 
American adults owned a mobile phone during the years 2009-2012. However, in 2009, only 25\% of them used the mobile phone to access the Internet, while in $2012,56 \%$ of them did so. By the beginning of $2014,90 \%$ of American adults had a cell phone, while $58 \%$ of them had a smartphone. (Pew Research Center, 2014).

Worldwide, the number of people owning a smartphone is increasing. Although it may seem difficult to use the mobile interface, customers are adopting this channel to get information. Surveys indicate that smartphone users learn how to use the applications of these devices and gradually adopt more applications (Smith, 2012). In order to improve information consumption, as well as information dissemination, there is a need to examine which information formats are more effective when accessed through mobile devices such as smartphones and tablets. Handheld mobile devices face obstacles due to their size, e.g., tiny screens, resolution, small keyboards, and connectivity limits (Barnes \& Huff, 2003; Gafni, 2008). If they are not satisfactorily taken care of by information providers, some of these factors may impair implementation success. To enable consumers to access information through handheld mobile devices in an appropriate manner, the information provider has to develop a suitable interface, technically adapted to the characteristics of mobile devices and to different operating systems of smartphones and tablets. These interfaces need to be specially designed to fit mobile screens due to different usage modes, such as touch screens (Parsons, 2007). For mobile devices, each information format requires specific development in order to make it accessible, as well as to cope with the informing challenge (Cohen, 2009; Gill \& Bhattacherjee, 2007, 2009) and deliver the information effectively.

The purpose of this study is to examine diverse information media in order to identify those formats that are most suitable for consumption via handheld mobile devices. The novelty of this research is that it takes the perspective of the users and measures their preferences objectively by analyzing actual data of their relative use of handheld mobile devices and desktop devices for consumption of information presented in various formats.

Furthermore, until the development of smartphones and similar devices, it was assumed that due to their size constraint mobile devices were most suitable for parsimonious information formats (Barnes \& Huff, 2003), preferably short text. Prior research indicated that incongruent display of information designed for other devices may impair its value, e.g., by negatively influencing critical reading (Eshet-Alkalai, \& Geri, 2010). However, it seems that the current handheld mobile devices may be appropriate for consumption of rich formats of information, such as video and audio, but may be less convenient for reading lengthy texts (Gafni \& Geri, 2013a).

This study focuses on mobile learning (m-learning) and examines consumption of information in various formats by students via desktop and handheld mobile devices. M-learning contexts were chosen, rather than a commercial setting, since in a learning environment the interests of information providers (i.e., the instructors) are in accord with those of the information consumers (i.e., the students), whereas in commercial settings there may be conflicts of interests.

The study is based on actual usage data of information consumption in diverse formats by students of the Open University of Israel. The study aims to discover, using the logs accumulated for the desktop and the mobile devices, the differences of usage and the adoption rate of the new handheld mobile devices by the students and the difference in access to diverse formats of information offered to them on course Websites.

Understanding the differences or similarities in handheld mobile devices and desktop devices use can provide useful guidelines for deciding which contents are suitable for use through mobile devices. The conclusions of this study may be applicable for either m-learning systems or business environments where, for example, firms need to decide which format of marketing information is preferable when using handheld mobile devices. 


\section{Theoretical Background}

Few studies have examined the differences between online content consumption via personal computing (PC) desktop devices and handheld mobile devices (Chae \& Kim, 2003; Church \& Smith, 2008; Cui \& Roto, 2008; Gafni \& Geri, 2013a; Geri, Gafni, \& Winer, 2014b; Inoue et al., 2012; Tossell, Kortum, Rahmati, Shepard, \& Zhong, 2012). Although both environments are used for information retrieval, there are differences between the devices in the manner of usage (Halvey, Keane, \& Smyth, 2006).

The value of handheld mobile devices includes ubiquity, personalization, and flexibility, as mobile devices users tend to access the same content as they access via PC desktop devices (Hinman, Spasojevic, \& Isomursa, 2008). Sometimes users prefer the mobile devices although there is a PC nearby, mainly due to convenience, as well as laziness (Nylander, Lundquist, \& Brännström, 2009). There are contradicting results reported in the literature regarding substitutability or complementarity of stationary PC and handheld mobile devices (Barth \& Heimeshoff, 2012).

Cognitive fit theory (Vessey, 1991), which was also applied for mobile devices adoption studies (Adipat, Zhang, \& Zhou, 2011; Lee, Cheng, \& Cheng, 2007), suggests that compatibility between task and information presentation format results in superior task performance. On the one hand, people tend to perform more and more tasks via their handheld mobile devices, but, on the other hand, learning requires concentration, and therefore it may be best performed via personal computing desktop devices in a comfortable and quiet environment. Furthermore, some mobile technologies or applications are relatively new, and it takes time for innovations to diffuse (Cochrane \& Bateman, 2010; Rogers, 2003). Hence, we hypothesize that:

H1: Over time, the use of handheld mobile devices for consumption of information in formats that are suitable for these devices would increase.

Tablets have larger screens than smartphones, hence they might be more convenient for information consumption. Nevertheless, smartphones are much more ubiquitous than tablets, so from that aspect, it would have been expected that the rate of use of smartphones would be greater than that of tablets (Rogers, 2003). Furthermore, smartphones enable access to the Internet via Wi-Fi, as well as via the phone, whereas this may not be the case for some tablets that are dependent on the availability of Wi-Fi. Concerning the context of learning and various information media, some formats may not be fit for smartphones, tablets, or both. Critical reading, which is required for studying, might be harder in mobile environments, especially via the tiny smartphone screen, unless the content is adapted to the device (Eshet-Alkalai, \& Geri, 2010). Another consideration is the notion that smartphones are disruptive for tablets (Downes \& Nunes, 2013). Therefore, we propose that:

H2: Smartphones would be used more than tablets for consumption of information media that are fit for smartphones.

\section{Methodology}

This study utilized the data sets that online information systems produce when recording and storing logs of user activities and used data analytics (Geri, Gafni, \& Winer, 2014a; LaValle, Lesser, Shockley, Hopkins, \& Kruschwitz, 2011; Levy \& Ramim, 2012) for objectively investigating the rate of adoption of handheld mobile devices, while considering various information formats.

The data was collected by Google Analytics (Clifton, 2012; Pakkala, Presser, \& Christensen, 2012) from course Websites of the Open University of Israel that offers its students a choice of distance and blended learning models. 
There are several ways in which the use of information provided on a Webpage may be measured. The main levels are subscribers, traffic, and revenues. In this study, the relevant level was traffic, which was measured by pageviews of specific Webpages via personal computing desktop devices (collectively for personal computers, laptops, and notebooks) and via handheld mobile devices (separately for smartphones and tablets). Among the possibilities offered by Google Analytics, it provides information on pageviews according to the device that was used to access the Webpage.

It should be noted that Google Analytics offers several possibilities to collect data, which are sometimes determined automatically by certain attributes of the required data. Google Analytics' procedure, which is most relevant in the context of this study, is providing sample data instead of actual data when the amount of data that the analyst asked for is large (e.g., the number of pageviews via certain devices of the homepage of a course with 500 enrolled students during a semester). However, our measurement of the pageviews via Google Analytics was based on the complete data, as opposed to the sample data automatically provided when the required amount of data is large. This accurate measurement of the total pageviews involved much manual work, but it was necessary because pilot testing of the automatic sample data provided by Google Analytics revealed inconsistencies.

The content of a course Website contains information in various formats. A certain Webpage may contain information or provide access to information in one or several formats. The structure of the course Websites enables measuring the pageviews of the following information media:

- The course homepage, which contains links to various information media and serves as a portal to the content and activities within the course Website.

- Discussion boards (also called forums), which contain mainly short text messages and enable communication between the instructors and the students, as well as among the students.

- Resources, which mostly include written material, such as assignments, solutions to assignments, and sample exams. Usually these are MS Office documents.

- Presentations, which are usually PowerPoint slides that instructors use.

- Video lectures, which may serve as a substitute for attending face-to-face meetings or as a means to reinforce learning.

- Books, which are the textbooks used in the course. However, books were available since the second measured semester (2013B, see below) and on just two of the examined course Websites, hence the observations regarding their use are exploratory in order to assist further research. Furthermore, a book was downloaded only once to the student's device, and there was no way to measure actual reading data.

The sample included five undergraduate regular social sciences courses: Information Systems, Marketing, Political Science, Organizational Behavior, and Price Theory. One of the courses, Information Systems, was a fully online course. The other courses were taught mainly via a blended learning mode, although students could choose to study them via a fully online mode, and about $5 \%-10 \%$ of them chose that option. These courses were selected because they represented diverse sorts of courses, and they were generally considered as excellent courses with active Websites. Undergraduate students were chosen because prior studies indicated that people who belonged to generation Y (which refers to those born from the years 1982-3 until the year 2000) were more inclined to adopt mobile devices applications (Gafni \& Geri, 2013b), as younger people tend to adopt new technologies (Morris \& Venkatesh, 2000). 
The sample included a total of 11,557 students, who studied the five courses during one of the following three semesters: 2013A (October 2012 - February 2013), 4,031 students; 2013 B (March 2013 - July 2013), 3,686 students; and 2014 A (October 2013 - February 2014), 3,840 students. Each course was divided to three periods: beginning, middle, and end of the semester. The purpose of this division was to observe rates of changes over time in the adoption of handheld mobile devices.

\section{Results}

The first hypothesis suggested that over time there will be increased use of handheld mobile devices for consumption of information in formats that are suitable for these devices. Table 1 presents the rates of personal computing desktop devices, smartphones, and tablets use for consumption of diverse information media during three sub-periods: The beginning (first) period of semester 2013A; the beginning of semester 2014A, which is a year after the first reported period; and the end of semester 2014A. Table 1 also presents the results of $\chi^{2}$ tests that were performed on the pageviews numerical data (i.e., the number of pageviews via each sort of device). The rate of use is reported since it has a higher informing value than the numerical pageview data.

As shown in Table 1, there was a significant increased use of handheld devices over time, as $\mathrm{H} 1$ suggested, for accessing course homepages, discussion forums, online video lectures, and resources. However, H1 was not supported for presentations and books. As depicted in Figure 1, the increase of smartphone use rate was greater than the increase of tablet use. The relative highest changes in smartphone rate of adoption were observed in forums, which grew from $1.3 \%$ at the beginning of $2013 \mathrm{a}$ to $4.6 \%$ at the end of $2014 \mathrm{~b}$, and in online video lectures, which grew from $2.2 \%$ at the beginning of $2013 \mathrm{a}$ to $5.6 \%$ at the end of $2014 \mathrm{~b}$.

Table 1: Rates of personal computing (PC) desktop devices, smartphones, and tablets use for consumption of diverse information media during three periods

\begin{tabular}{|c|c|c|c|c|c|c|c|c|c|c|c|}
\hline \multirow{2}{*}{$\begin{array}{l}\text { Information } \\
\text { medium }\end{array}$} & \multicolumn{3}{|c|}{$\begin{array}{l}\text { 2013A Beginning } \\
(2013 \mathrm{Ab})\end{array}$} & \multicolumn{3}{|c|}{$\begin{array}{l}\text { 2014A Beginning } \\
(2014 \mathrm{Ab})\end{array}$} & \multicolumn{3}{|c|}{$\begin{array}{c}\text { 2014A End } \\
\text { (2014Ae) }\end{array}$} & \multicolumn{2}{|c|}{$\chi^{2}, d f=2$} \\
\hline & $\begin{array}{c}\mathrm{PC} \\
\%\end{array}$ & $\begin{array}{c}\text { Smart } \\
\text { phone } \\
\%\end{array}$ & $\begin{array}{c}\text { Tablet } \\
\%\end{array}$ & $\begin{array}{c}\mathrm{PC} \\
\%\end{array}$ & $\begin{array}{c}\text { Smart } \\
\text { phone } \\
\%\end{array}$ & $\begin{array}{c}\text { Tablet } \\
\%\end{array}$ & $\begin{array}{l}\mathrm{PC} \\
\%\end{array}$ & $\begin{array}{c}\text { Smart } \\
\text { phone } \\
\%\end{array}$ & $\begin{array}{c}\text { Tablet } \\
\%\end{array}$ & \begin{tabular}{|c|}
$2013 \mathrm{Ab}$ \\
Vs. \\
$2014 \mathrm{Ab}$
\end{tabular} & \begin{tabular}{|l}
$2013 \mathrm{Ab}$ \\
Vs. \\
$2014 \mathrm{Ae}$
\end{tabular} \\
\hline All pages & 96.2 & 2.3 & 1.5 & 93.2 & 4.2 & 2.6 & 93.2 & 4.4 & 2.4 & $\begin{array}{c}809.9 \\
* *\end{array}$ & $\begin{array}{c}1,023.5 \\
* *\end{array}$ \\
\hline Homepage & 96.2 & 2.4 & 1.4 & 93.9 & 4.0 & 2.1 & 93.1 & 4.7 & 2.2 & $\begin{array}{c}326.2 \\
* *\end{array}$ & $\begin{array}{c}707.1 \\
* *\end{array}$ \\
\hline Forums & 98.1 & 1.3 & 0.6 & 94.6 & 3.2 & 2.2 & 94.1 & 4.6 & 1.3 & $\begin{array}{c}31.4 \\
* *\end{array}$ & $\begin{array}{c}39.2 \\
* *\end{array}$ \\
\hline Resources & 97.7 & 1.4 & 0.9 & 95.7 & 2.1 & 2.2 & 96.4 & 1.8 & 1.8 & $\begin{array}{l}53.6 \\
* *\end{array}$ & $\begin{array}{l}32.4 \\
* *\end{array}$ \\
\hline Presentations & 92.1 & 3.7 & 4.2 & 92.9 & 3.6 & 3.5 & 93.4 & 3.3 & 3.3 & 1.7 & 3.9 \\
\hline Video lectures & 96.2 & 2.2 & 1.6 & 90.2 & 5.9 & 3.9 & 91.1 & 5.6 & 3.3 & $\begin{array}{c}461.9 \\
* *\end{array}$ & $\begin{array}{c}408.0 \\
* *\end{array}$ \\
\hline $\begin{array}{l}\text { Books } \\
\text { (2013B data } \\
\text { instead of 2013A) }\end{array}$ & 86.8 & 4.4 & 8.8 & 85.0 & 5.9 & 9.1 & 94.4 & 3.1 & 2.5 & 0.4 & $\begin{array}{c}6.6 \\
*\end{array}$ \\
\hline
\end{tabular}

** Significant $\mathrm{p}<.0001, *$ significant $\mathrm{p}<.05$ 

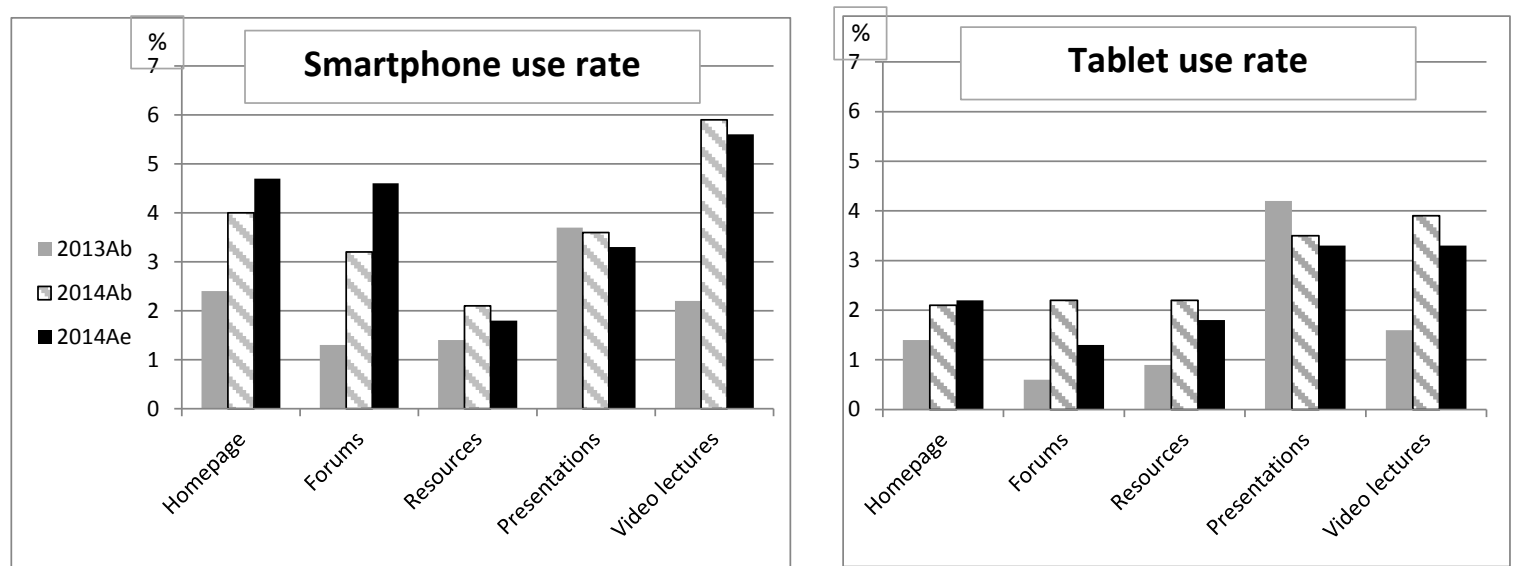

Figure 1: Smartphone and tablet adoption rate at the beginning of semester 2013A, the beginning of semester $2014 \mathrm{~A}$, and the end of semester $2014 \mathrm{~A}$

$\mathrm{H} 2$ concerned the use of tablets relatively to the use of smartphones. As Table 2 shows and Figure 2 presents, on average, smartphones were significantly used more than tablets for accessing the course homepage, forums, and video lectures. Contrarily, consumption of digital books was greater via tablets. However, there were no significant differences in the rate of consuming resources and presentations, which was $2.75 \%-3.25 \%$, and was relatively lower than that of other information media. It is noteworthy that for smartphones these rates were smaller than those of other formats, whereas for tablets these rates were higher than those of most formats, except for books.

\begin{tabular}{|c|c|c|c|c|c|c|}
\hline \multicolumn{7}{|c|}{$\begin{array}{l}\text { Table 2: Paired samples t-tests of smartphone and tablet use rate } \\
\text { for consumption of diverse information media }\end{array}$} \\
\hline $\begin{array}{l}\text { Information } \\
\text { medium }\end{array}$ & $\begin{array}{c}\text { Smartphone } \\
\text { mean \% } \\
\text { (SD) }\end{array}$ & $\begin{array}{c}\text { Tablet } \\
\text { mean \% } \\
\text { (SD) }\end{array}$ & $\mathbf{n}$ & t & df & $\begin{array}{c}\text { Cohen's } \\
\text { d }\end{array}$ \\
\hline All pages & $\begin{array}{c}4.00 \\
(1.76)\end{array}$ & $\begin{array}{l}1.97 \\
(0.97)\end{array}$ & 15 & $\begin{array}{c}5.481 \\
* *\end{array}$ & 14 & $\begin{array}{l}1.43 \\
\text { Large }\end{array}$ \\
\hline Homepage & $\begin{array}{c}4.13 \\
(1.80)\end{array}$ & $\begin{array}{l}1.60 \\
(0.90)\end{array}$ & 15 & $\begin{array}{c}6.141 \\
* *\end{array}$ & 14 & $\begin{array}{l}1.76 \\
\text { Large }\end{array}$ \\
\hline Forums & $\begin{array}{c}4.10 \\
(1.55)\end{array}$ & $\begin{array}{c}1.20 \\
(0.77)\end{array}$ & 15 & $\begin{array}{c}6.487 \\
* *\end{array}$ & 14 & $\begin{array}{c}2.29 \\
\text { Large }\end{array}$ \\
\hline Resources & $\begin{array}{c}2.75 \\
(2.18)\end{array}$ & $\begin{array}{c}3.25 \\
(4.65)\end{array}$ & 12 & $\begin{array}{c}-0.37 \\
\text { ns }\end{array}$ & 11 & $\begin{array}{l}-0.28 \\
\text { Small }\end{array}$ \\
\hline Presentations & $\begin{array}{c}3.17 \\
(7.50)\end{array}$ & $\begin{array}{c}2.83 \\
(7.50)\end{array}$ & 6 & $\begin{array}{c}0.674 \\
\text { ns }\end{array}$ & 5 & $\begin{array}{l}0.05 \\
\text { NA }\end{array}$ \\
\hline $\begin{array}{l}\text { Video lec- } \\
\text { tures }\end{array}$ & $\begin{array}{c}4.80 \\
(3.40)\end{array}$ & $\begin{array}{c}2.70 \\
(1.50)\end{array}$ & 15 & $\begin{array}{c}2.924 \\
*\end{array}$ & 14 & $\begin{array}{c}0.80 \\
\text { Large }\end{array}$ \\
\hline $\begin{array}{l}\text { Books } \\
\text { (2013B and } \\
2014 \mathrm{~A})\end{array}$ & $\begin{array}{c}3.00 \\
(1.41)\end{array}$ & $\begin{array}{l}5.50 \\
(0.71)\end{array}$ & 2 & $\begin{array}{c}-5.000 \\
\text { ns }\end{array}$ & 1 & $\begin{array}{l}-2.24 \\
\text { Large }\end{array}$ \\
\hline
\end{tabular}

$* *$ Significant $\mathrm{p}<.0001, *$ significant $\mathrm{p}<.05, \mathrm{~ns}=$ not significant 


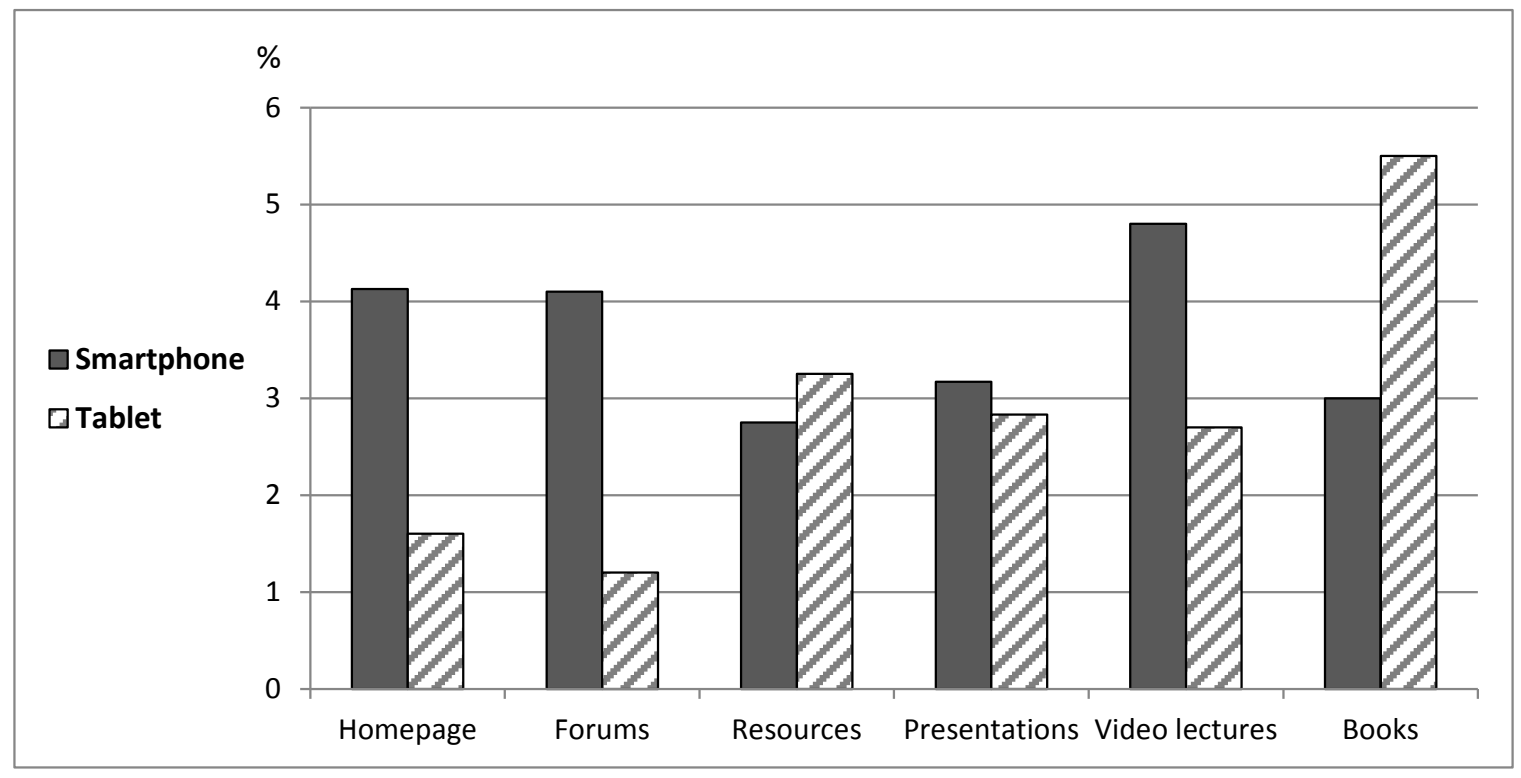

Figure 2: Mean Smartphone and tablet adoption rates

\section{Discussion}

\section{Theoretical Implications, Limitations, and Further Research}

The findings indicate that both hypotheses were generally supported; over time, there was increased use of handheld mobile devices, and the increase in the use of smartphones was significantly higher than that of tablets, though the results were varied and were not significant for all the examined information media. The differences between information media suggest that indeed some devices are currently more suitable for certain information formats and user actions. The relatively higher increase in the use of smartphones for online video content is noteworthy, not only for practical purposes, as further discussed in the following section, but mainly from a theoretical perspective. Whereas mobile devices were considered limited and appropriate for parsimonious information formats (e.g., Barnes \& Huff, 2003), as technologies change some sorts of mobile handheld devices become appropriate for consumption of rich information formats, such as videos. While the technical aspects of these changes, e.g., adequate bandwidth, are somewhat obvious, the cognitive aspects are an interesting direction for further research and may also provide practical opportunities.

This study concerned consumption of content in various information media and focused on the media rather than the content. Therefore, the findings are applicable to other e-learning systems, as well as any other system where the users may choose the device with which to access content of a Website. Nevertheless, the generalizability of the findings should be strengthened by further research conducted in other environments.

Data analytics and the use of information provided by Google Analytics provide objective data, which is a major methodological strength of this study. However, the accuracy of Google Analytics is somewhat limited. Furthermore, the analyzed data observed quantitative data of pageviews, but could not address the qualitative aspects of these activities. Hence, although the data is adequate as a source of accurate trends, it is desirable to investigate these issues with other methodologies like surveys, interviews, and experiments. 


\section{Practical Implications}

Currently, most students prefer personal computing desktop devices for consumption of all sorts of information media. These findings are in line with prior research, which concerned the use of online video lectures via handheld mobile devices for exam preparation (Geri, Gafni, \& Winer, 2014b). Notwithstanding, our findings demonstrate the increasing use of smartphones, especially for accessing forums and online video lectures. Considering the investments and efforts required for adapting content for mobile handheld devices, our findings suggest that academic institutions should focus on increasing the usability of consuming the content of forums and online video lectures via smartphones. However, consumption of all information media via tablets was scant, except for digital books. It should be noted that since tablets are bigger than smartphones it is less convenient to carry them. As smartphones become a bit bigger, but yet much smaller than tablets, consumers prefer smartphones, as reflected in worldwide declining tablet sales. Books were the only content that was more consumed via tablets than via smartphones (although the sample was limited, so this finding is less conclusive). Therefore, it seems that books are the only digital content that should be adapted to tablets. An alternative practical implication is that digital books should be adjusted to be read via smartphones, because the current situation may be a consequence of a "chicken and egg" problem, i.e., students did not consume digital books via smartphones because the content was not adapted to smartphones, and if the content would be modified, then its consumption via this device would increase.

\section{Conclusion}

Are handheld mobile devices disruptive for personal computing desktop devices (Downes \& Nunes, 2013)? Our findings suggest that the answer is no, or at least not yet, as about $90 \%$ or more of the pageviews were via PC devices. Students may use mobile handheld devices to access various information media and perhaps compose short text messages that are posted on forums. However, PC devices are still the main means for preparing assignments, and, as our data demonstrate, also for consuming content via all sorts of information media. Nevertheless, are smartphones disruptive for tablets? Our findings support this trend, as we have found that the rate of smartphone use for consuming learning content in diverse information media is gradually increasing, as time goes by, whereas the rate of tablet use for these purposes is almost stagnant.

There are few studies that investigate differences between usage patterns of personal computing desktop devices and handheld mobile devices, and this study adds to this body of knowledge. Nonetheless, the unique contribution of the current study is the examination of evolving consumption patterns of various information media via handheld mobile devices. The most promising direction for smartphones emanating from our findings is providing online video content.

\section{Acknowledgements}

The authors gratefully acknowledge that this research was supported by a grant from the Research fund of The Academic College of Tel Aviv Yaffo.

\section{References}

Adipat, B., Zhang, D., \& Zhou, L. (2011). The effects of tree-view based presentation adaptation on mobile web browsing. MIS Quarterly, 35(1), 99-122.

Barnes, S., \& Huff, S. (2003). Rising sun: iMode and the wireless Internet. Communications of the ACM, 46(11), 89-96.

Barth, A. K., \& Heimeshoff, U. (2012). How large is the magnitude of fixed-mobile call substitution? Empirical evidence from 16 European countries. 23rd European Regional ITS Conference, Vienna 
2012. International Telecommunications Society (ITS). Retrieved from: http://econstor.eu/bitstream/10419/60391/1/720203082.pdf

Chae, M., \& Kim, J. (2003). What's so different about the mobile Internet? Communications of the ACM, $46(12), 240-247$.

Church, K., \& Smyth, B. (2008). Who, what, where \& when: A new approach to mobile search. Proceedings of the 13th International Conference on Intelligent User Interfaces (IUI '08).

Clifton, B. (2012). Advanced web metrics with Google Analytics. Indianapolis: Wiley Publishing Inc.

Cochrane, T., \& Bateman, R. (2010). Smartphones give you wings: Pedagogical affordances of mobile Web 2.0. Australasian Journal of Educational Technology, 26(1), 1-14. Retrieved from http://ascilite.org.au/ajet/submission/index.php/AJET/article/view/1098

Cohen, E. (2009). A philosophy of informing science. Informing Science, 12, 1-15. Retrieved from http://inform.nu/Articles/Vol12/ISJv12p001-015Cohen399.pdf

Cui Y., \& Roto, V. (2008). How people use the web on mobile devices. Proceedings of $W W W ' 08,905-$ 914.

Downes, L., \& Nunes, P. F. (2013). Big-bang disruption. Harvard Business Review, 91(3), 44-56.

Duggan, M., \& Rainie, L. (2012). Cell phone activities 2012. Pew Research Center 2012. Retrieved from: http://pewInternet.org/ /media//Files/Reports/2012/PIP_CellActivities_11.25.pdf

Eshet-Alkalai, Y., \& Geri, N. (2010). Does the medium affect the message? The effect of congruent versus incongruent display on critical reading. Human Systems Management, 29(4), 243-251.

Gafni, R. (2008). Framework for quality metrics in mobile-wireless information systems. Interdisciplinary Journal of Information, Knowledge, and Management, 3, 23-38. Retrieved from http://ijikm.org/Volume3/IJIKMv3p023-038Gafni358.pdf

Gafni, R., \& Geri, N. (2013a). Adoption patterns of a juridical knowledge base. Journal of Information, Information Technology, and Organizations, 8, 25-39. Retrieved from http://www.iiakm.org/jiito/articles/Volume 8/JIITOv8p025-039Gafni-Geri.pdf

Gafni, R., \& Geri, N. (2013b). Generation Y versus generation X: Differences in smartphone adaptation. In Y. Eshet-Alkalai, A. Caspi, S. Eden, N. Geri, Y. Kalman, \& Y. Yair (eds). Proceedings of the 8th Chais Conference on Innovation and Learning Technologies (pp. 18-23), February 19-20, 2013, Raanana, The Open University of Israel. Retrieved from http://www.openu.ac.il/innovation/chais2013/download/b1 4.pdf

Geri, N., Gafni, R., \& Winer, A. (2014a). The u-curve of e-learning: Course website and online video use in blended and distance learning. Interdisciplinary Journal of E-Learning and Learning Objects, 10, 116. Retrieved from http://www.ijello.org/Volume10/IJELLOv10p001-016Geri0473.pdf

Geri, N., Gafni, R., \& Winer, A. (2014b). Emerging patterns of online video lectures and handheld mobile devices use for exam preparation. In Y. Eshet-Alkalai, A. Caspi, N. Geri, Y. Kalman, V. Silber-Varod, $\&$ Y. Yair (eds.), Proceedings of the 9th Chais Conference for the Study of Innovation and Learning Technologies: Learning in the technological era, (pp. 52-59), February 11-12, 2014, Raanana, The Open University of Israel. Retrieved from http://www.openu.ac.il/innovation/chais2014/download/C23.pdf

Gill, T. G., \& Bhattacherjee, A. (2007). The informing sciences at a crossroads: The role of the client. Informing Science, 10, 17-39. Retrieved from http://inform.nu/Articles/Vol10/ISJv10p017039Gill317.pdf

Gill, T. G., \& Bhattacherjee, A. (2009). Whom are we informing? Issues and recommendations for MIS research from an informing science perspective. MIS Quarterly, 33(2), 217-235.

Halvey, M., Keane, M., \& Smyth, B. (2006). Mobile Web surfing is the same as Web surfing. Communications of the ACM, 49(3), 76-81. 
Hinman, R., Spasojevic, M., \& Isomursa, P. (2008). They call it surfing for a reason: Identifying mobile Internet needs through PC Internet deprivation. In CHI '08: Proceedings of the 26th International Conference on Human Factors in Computing Systems, 2195-2208, New York, USA, ACM.

Inoue, A., Nagahata, R., Ishii, Y., Dobashi, M., Kaku, R., \& Iwashita, M. (2012). Mobile internet-access behavior analysis. In Software Engineering, Artificial Intelligence, Networking and Parallel \& Distributed Computing (SNPD), 2012 13th ACIS International Conference, 766-770, IEEE.

LaValle, S., Lesser, E., Shockley, R., Hopkins, M. S., \& Kruschwitz, N. (2011) Big data, analytics and the path from insights to value. MIT Sloan Management Review, 52(2), 21-32.

Lee, C. C., Cheng, H. K., \& Cheng, H. H. (2007). An empirical study of mobile commerce in insurance industry: Task-technology fit and individual differences. Decision Support Systems, 43(1), 95-110.

Levy, Y., \& Ramim, M. M. (2012). A study of online exams procrastination using data analytics techniques. Interdisciplinary Journal of E-Learning and Learning Objects, 8, 97-113. Retrieved from http://www.ijello.org/Volume8/IJELLOv8p097-113Levy0804.pdf

Morris, M. G., \& Venkatesh, V. (2000). Age differences in technology adoption decisions: Implications for a changing work force. Personnel Psychology, 53, 375-403.

Nylander, S., Lundquist, T., \& Brännström, A. (2009). At home and with computer access - Why and where people use cell phones to access the Internet. Proceedings of the SIGCHI Conference on Human Factors in Computing Systems, 1639-1642.

Pakkala, H., Presser, K., \& Christensen, T. (2012). Using Google Analytics to measure visitor statistics: The case of food composition websites. International Journal of Information Management, 32(6), 504512.

Parsons, D. (2007). Mobile portal technologies and business models. In A. Tatnall, (Ed.), Encyclopedia of portal technology and applications (pp, 583-586). Hershey, PA: IGI Global.

Pew Research Center (2014). Cell phone and smartphone ownership demographics. Retrieved from http://www.pewinternet.org/data-trend/mobile/cell-phone-and-smartphone-ownership-demographics/

Rogers, E. M. (2003). Diffusion of innovations (5th ed.). New-York: The Free Press.

Smith A. (2012). 46\% of American adults are smartphone owners. Pew Research Center. Retrieved from http://pewInternet.org/ /media//Files/Reports/2012/Smartphone\%20ownership\%202012.pdf

Tossell, C., Kortum, P., Rahmati, A., Shepard, C., \& Zhong, L. (2012). Characterizing web use on smartphones. Proceedings of the 2012 ACM Annual Conference on Human Factors in Computing Systems, 2769-2778.

Vessey, I. (1991). Cognitive fit: A theory-based analysis of the graphs versus tables literature. Decision Sciences, 22(2), 219-240.

\section{Biographies}

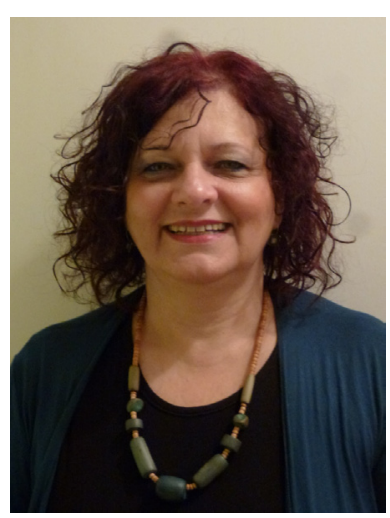

Ruti Gafni is the Head of the Management of Information Systems BA program at The Academic College of Tel Aviv Yaffo. She holds a $\mathrm{PhD}$ from Bar-Ilan University, Israel (in the Business Administration School), focusing on Information Systems, an M.Sc. from Tel Aviv University and a BA (Cum Laude) in Economics and Computer Science from Bar-Ilan University. She has more than 30 years of practical experience as Project Manager and Analyst of information systems. She also teaches in the Management and Economics MBA program at the Open University of Israel. 


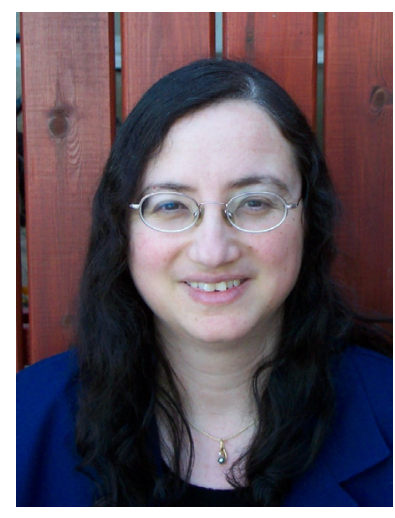

Nitza Geri is an Associate Professor at the Open University of Israel, Department of Management and Economics, and Head of the Research Center for Innovation in Learning Technologies. She holds a B.A. in Accounting and Economics, an M.Sc. in Management Sciences and a Ph.D. in Technology and Information Systems Management from Tel-Aviv University. Nitza is a CPA (Israel) and prior to her academic career she had over 12 years of business experience. Her research interests and publications focus on various aspects of the value of information and knowledge, as well as adoption, implementation, and continued use of information systems, including: strategic information systems, e-business, information economics, attention economy, knowledge management, value creation and the Theory of Constraints, managerial aspects of e-learning systems. Personal site: http://www.openu.ac.il/Personal_sites/nitza-geri.html 